\title{
Proměny účelu účetnictví v různých obdobích existence českého státu*
}

\section{PAVLA SLAVÍČKOVÁ}

Slavícková, Pavla: Changes of Purpose of Accounting in Different Periods of the Czech State Accounting can generally be understood as a set of accounting records kept for a particular purpose and organized according to the selected accounting system into a solid structure. As such, accounting is able to follow the changing needs, internal (accountant, manager, owner, etc.) or external users (local authority, government etc.). For these reasons, understanding the purpose of accounting in the past seems to be crucial for studying historical accounting sources. The aim of the article is to describe the development of accounting in various periods of the history of the Czech state in relation to the state legal system and to answer the question whether there is a connection between the state and its establishment and the content and form of the accounting system used at that time.

Key Words Accounting; History; Czech Lands; State; Law

doi.org/10.15452/Historica.2020.11.0001

Contact Univerzita Palackéhov Olomouci; pavla.slavickova@upol.cz

Účetnictví lze velmi obecně definovat jako soubor účetních záznamů vedených za určitým cílem a uspořádaných dle použité účetní soustavy do pevné struktury. Jako takové bylo proto účetnictví schopno plnit v různých obdobích různé požadavky, které na něho byly ze strany uživatelů kladeny, a to jak interní (účetní, správce, vlastník apod.), tak i externí (úřad, stát). Jako klíčové pro pochopení vývoje účetnictví v minulosti se jeví identifikace účelu, za kterým byly v různých historických obdobích účetní záznamy vedeny, a jak se tento účel promítal do použité účetní soustavy. Cílem článku je proto charakterizovat podstatu účetnictví v různých etapách vývoje českého státu a odpovědět na otázku, jakému účelu v kterých obdobích účetnictví sloužilo, zdali existuje vazba mezi státem a jeho politickým zř́izením a podobou tehdy používané účetní soustavy.

Mluvit přitom můžeme v našem prostředí hned o několika účetních soustavách, které byly používány v minulosti na našem území. Jedná se o účetnictví jednoduché, podvojné, kamerální a tzv. účetnictví správní, přičemž každá měla v praxi celou škálu variant. Jako správní účetnictví rozumíme účetní záznamy vedené ve stř̌edověku a v raném novověku, pro něž je typické oddělení peněžní a hmotné evidence, sledování peněžních toků (příjmů a výdajů), různorodost v evidenci závazků (dluhů a pohledávek), nedůsledné oceňování, absence rozpočtu, nejednotná struktura knih a dalších druhů účetních záznamů aj. ${ }^{1}$ Vznik kamerálního účetnictví jen nejčastěji spojován s obdobím Marie Terezie a jeho podstata spočívá ve sledování peněžních toků v návaznosti na stanovený rozpočet, tedy tzv. plánu

\footnotetext{
Tento článek byl zpracován díky finanční podpoře GAČR, projekt č. 19-07805S.

Detailně SLAVÍČKOVÁ, Pavla: Účetnictví mezi tradicí a racionalitou v českých zemích od středověku do počátku 18. století. Praha 2017.
} 
(náležitost) a plnění (plat). Z tohoto důvodu byla tato účetní soustava využívána zejména rozpočtovými organizacemi. ${ }^{2}$ Rozdíl mezi jednoduchým a podvojným účetnictvím je ve způsobu účtování, kdy podvojné zachycuje náklady a výnosy, zatímco jednoduché sleduje př́imy a výdaje. Díky tomu lze v podvojném účetnictví zjistit hospodářský výsledek (výkaz ztráty a zisku), zatímco u jednoduchého je hlavní výkaz peněžních toků (cash flow). Klíčový princip podvojného účetnictví pak spočívá v zaúčtování každé operace vždy dvakrát, na dva různé účty. Díky tomu vzniká známý vztah strany Má dáti a strany Dal, kdy součet strany Má dáti a součet strany Dal po uzavření účtů musí být vždy shodný. Zatímco vznik a vývoj správního účetnictví byl již z podstatné části ozřejměn, ${ }^{4}$ výzkum dalších účetních soustav používaných v minulosti na našem území je na samém počátku. Následující text je proto možné chápat i jako př́ispěvek k této problematice.

\section{Přehled historiografie o českých dějinách účetnictví}

Přehledová studie o vývoji účetnictví u nás od počátků do současnosti na rozdíl od zahraničí u nás stále chybí. ${ }^{5}$ Od roku 2014 máme k dispozici Malé dějiny účetnictví, které se však zaměřují hlavně na vývoj v 19. a 20. století a starší období zmiňují pouze okrajově. ${ }^{6}$ První pokusy o sepsání dějin účetnictví u nás se datují již do konce 19. století, badatelský zájem Karla Petra Kheila mladšího však zůstal omezen na účetní památky zahraniční provenience, díky čemuž však máme dnes mimo jiné k dispozici spis o Benedettu Cotruglim. ${ }^{7}$ Na jeho práci (jak sám deklaruje) poté navázal Alfréd Eisner, jehož Nejstarší památky a spisy účetnické vydané v roce 1920 jsou zřejmě prvním přehledem o dějinách účetnictví publikovaným v češtině, nicméně zaměřeném zejména na vývoj mimo naše území. ${ }^{8}$ Podobný obsah pak měla i díla dalších autorů z období před rokem 1945, at' už zmíníme Stručné dějiny účetnictví Bohumila Štursy, Dějiny účetnictví Hugo Raulicha, nebo stejnojmenné dílo Josefa Fialy. ${ }^{9}$

Období po roce 1945 v tomto směru žádnou větší změnu nepřineslo, za zmínku zde stojí zpravidla opomíjená dlouhá řada drobných textů od Jaroslava Kubeši, které vycházely od 50. do 70. let v časopise Účetnictví. Ty seznamovaly české publikum s informacemi o významných osobnostech nebo výročích z historie účetnictví, a to nejen v Rusku (Sovětském svazu), ale i v Itálii, Francii, Nizozemí, Německu a jinde. ${ }^{10}$ Po roce 1989 pomyslné žezlo přehledových studií o dějinách účetnictví převzali ekonomové a profesní účetní, kteří však až na výjimku, kterou je Janhubův rozbor novohradských účtů, zůstali

\footnotetext{
RAULICH, Hugo: Kamerální účetnictví (v podnicích soukromých). Praha 1935.

3 JANHUBA, Miloslav: Teorie účetnictví : (výběr z problematiky). Praha 2010.

4 SLAVÍČKOVÁ, P.: Účetnictví.

5 Přehledné dějiny účetnictví v angličtině EDWARDS, John Richard: A history of Financial Accounting. London - New York 1989; CHATFIELD, Michael: A History of Accounting Thought. New York 1977; BROWN, Richard: A History of Accounting and Accountants. Edinburgh - London 1905; v němčině zejm. PENNDORF, Balduin: Geschichte der Buchhaltung in Deutschland. Leipzig 1913.

6 PUCHINGER, Zdeněk - SLAVÍČKOVÁ, Pavla: Malé dějiny účetnictví. Olomouc 2014.

$7 \quad$ KHEIL, Karel Petr: Benedetto Cotrugli Raugeo (Dubrovčan). Praha 1906.

$8 \quad$ EISNER, Alfréd: Nejstarší památky a spisy účetnické. Dvůr Králové nad Labem 1920.

9 ŠTURSA, Bohumil: Stručné dějiny účetnictví. s. l. s. d.; RAULICH, Hugo: Příspěvek k dějinám účetnictví. s. l. [1922]; TÝŽ: Dějiny účetnictví. Praha 1938; FIALA, Josef: Dějiny účetnictví. Praha 1935.

10 Časopis Účetnictví stále vychází, aktuálně ho vydává Svaz účetních České republiky. O vývoji časopisů PUCHINGER, Z. - SLAVÍČKOVÁ, P.: Malé dějiny.
} 
věrni prvorepublikové tradici. ${ }^{11}$ Slovensko se svých dějin účetnictví dočkalo díky Rudolfu Šlosárovi v roce 2008, ${ }^{12}$ kniha je však podobně jako na počátku zmíněné Malé dějiny účetnictví zaměřena zejména na vývoj v moderní době. Podobný charakter má i nejnovější počin pojednávající o financích a účetnictví ve 20. století vydaný v roce 2018 díky kolektivu autorů pod vedením Leoše Vítka. ${ }^{13}$ Napsání souhrnných dějin českého účetnictví v současnosti nadále brání nedostatečné zpracování řady klíčových výzkumných témat, bez kterých se nelze tohoto úkolu fakticky zhostit. Lze se proto domnívat, že si na kompletní popis vývoje účetnictví na našem území ještě nějaký čas budeme muset počkat.

\section{Základní rysy účetnictví před rokem 1848}

Účetnictví provází lidstvo od počátků civilizace. Nejstarším nálezem původem z našeho území je vrubovka nalezená v roce 1936 Karlem Absolonem v Dolních Věstonicích, pocházející z období lovců mamutů. ${ }^{14}$ Tato technika účetního záznamu překonala tisíciletí, o použití dřevěných vrubovek máme v pramenech doklad ještě v 19 . století. ${ }^{15} \mathrm{Nic}$ méně, nejstarší písemné prameny pochází z doby přece jen výrazně mladší. ${ }^{16}$ Obecně je za nejstarší u nás dochovaný účetní záznam označován fragment dochovaný v pražské Liber vetustissimus z 1310-1311. ${ }^{17}$ Soustavné účetní záznamy z konce 14 . století vlastní dodnes třeba České Budějovice, za unikátní soubory z nejstaršího období lze pokládat i účetní knihy dochované ve Znojmě, Stř́bř̌e, Brně, nebo Kutné Hoře. ${ }^{18}$ Od konce 15. v 16. a pak zejména po polovině 17. století množství účetní materie rapidně narůstá, typologicky se rozrůzňuje, záznamy se výrazně specializují, jsou zaváděny předepsané rubriky a forma záznamů získává pevnou strukturu. Jasně patrné je to zejména ve fondech velkostatků, jak již dříve ukázal Josef Hanzal, ${ }^{19}$ Jaroslav Čechura, ${ }^{20}$ nebo Robert Šimůnek. ${ }^{21}$ Z účetního hlediska je toto období typické svoji nejednotností, což bylo zřejmě způsobené

11 JANHUBA, Miloslav: Základy teorie účetnictví. Praha 2017; HÓTOVÁ, Renata: $Z$ dějin účetnictví. Economic Revue 4, 2003, s. 58-70.

12 ŠLOSÁR, Rudolf: Dejiny účtovnictva na Slovensku. Bratislava 2008.

13 VÍTEK, Leoš a kol.: Sto let financí a účetnictví na území České republiky. Praha 2018.

14 ABSOLON, Karel: Výzkum diluviální stanice lovců mamutů v Dolních Vẽstonicích na Pavlovských kopcích na Moravě. Brno 1945.

15 Jednalo se nejčastěji o hůl, tyč, př́í. větev, do které se pomocí zářezů zaznamenával potřebný počet uskutečněných operací. Na Moravě použiváno označení „rabuše“. Používání vrubovek zachytil ještě např́ílad Alois Jirásek v románu V cizích službách (1883). Od mechanismu vrubovek je odvozeno dodnes známé spojení „na vrub“ nebo „máš... vroubek.“

16 Přehled pramenů k dějinám účetnictví z nejstaršího období viz zejména: GRAUS, František: Dějiny venkovského lidu v Čechách v době predhusitské, 2. Praha 1957; Salaba, Josef: Př́spěvky ke kritice urbářu, pozemkových aj. knih, katastrů, map, starých účtů atd. Selský archiv XIV, 1923, č. 3-4, s. 1-31; Černý, Václav: Začátky našich hospodářských účtù. Časopis Společnosti Prátel starožitností 60, 1952, s. 121-133; Novotný, Jaroslav: Prameny k dějinám cen a mezd na Moravě v 16. a 17. století. Sborník archivních prací 18, 1968, č. 2, s. 478-497.

17 PÁTKOVÁ, Hana (ed.): Liber vetustissimus Antiquae Civitatis Pragensis 1310-1518. Praha 2011.

18 Detailně k účetní materii dochované v našem prostředí in: SLAVíČKOVÁ, Pavla: Účetnictví mezi tradicí a racionalitou v českých zemích od středověku do počátku 18. století. Praha 2017, s. 93-134.

19 HANZAL, Josef: Hospodářské patrimoniální účty předbělohorského období. Sborník archivních prací 16, 1966, č. 2, s. 397-419.

20 ČECHURA, Jaroslava: Hospodaření posledních Smiřických. Časopis Národního muzea : Řada historická 162, 1993, č. 3-4, s. 74-85.

21 ŠIMƯNEK, Robert: Správní systém šlechtického dominia v pozdně středověkých Čechách. Praha 2005. 
i absencí jakýchkoliv právních předpisů, které by tuto sféru hospodářského života nějak upravovaly. $^{22}$

V porovnání s vývojem v jiných zemích zejména západní a jižní Evropy, kde na toto téma existuje bohatý výzkum, ${ }^{23}$ byl vývoj u nás specifický také tím, že několik století přehlížel podvojné účetnictví, ${ }^{24}$ které se začalo v Evropě šířit zejména díky tisku Luca Pacioli po roce $1494 .{ }^{25} \mathrm{U}$ nás většina ekonomických jednotek používala ve středověku a raném novověku tzv. správní účetnictví, které však mělo velké množství variant. Jak je možné na soudobých pramenech vysledovat, specifika dané účetní soustavy se odvíjely nejen od velikosti a zaměření dané ekonomické jednotky, ale obvykle i od předchozí tradice, znalostí a zkušeností konkrétního písaře. ${ }^{26}$

Zásadní vliv na tento stav měl neexistující právní rámec, jehož absenci pouze do určité míry nahrazovaly hospodářské instrukce a různé teoretické př́ručky, které vycházely tiskem. ${ }^{27}$ Jejich obsah sice nebyl závazný, i tak se však tento žánr těšil v období raného novověku velké oblibě, nicméně účetní pokyny můžeme najít jen v některých. Konkrétně se jednalo oknížku Jana Brtvína zPloskovic a dílko nevelkého rozsahu od MikulášeČernobýla, které byly vydány tiskem společně v Praze v roce $1587 .{ }^{28} \mathrm{O}$ něco pozdější je pak spis Oculus Domini od Kryštofa Fischera vydaný poprvé v latinské verzi v roce 1679 a později byl přeložený do češtiny. ${ }^{29}$ Vzhledem k jejich charakteru lze tyto hospodářské manuály označit i za svého druhu první učebnice účetnictví a tedy za jakýsi první náběh k účetní unifikaci.

Právě systematizovaná výuka sehrála u nás při vývoji účetnictví klíčovou roli. První školy se zavedenou odbornou výukou se v Čechách a na Moravě objevily na přelomu 18. a 19. století. ${ }^{30}$ Jako príklad můžeme zmínit učiliště založené Karlem Egonem, knížetem z Fürstenberka na jeho panství v Lánech nebo selskou školu v Trnové u Zbraslavi, která vznikla z podnětu Jana Ferdinanda ze Schönfeldu (1750-1821). Součástí

22 SLAVÍC̆KOVÁ, Pavla: Právní úprava účetnictví v českých zemích v minulosti. Acta Universitatis Brunensis : Iuridica 449. Brno 2013, s. 295-304.

23 Viz např. JÄGER, Ernst Ludwig: Beiträge zur Geschichte der Doppelbuchhaltung. S. Vaduz 1978; BUHL, Herbert: Die geschichtlich begründete Kontentheorie ein Beitrag zur Geschichte der doppelten Buchhaltung. Stuttgart 1929; SEHLING, Emil: Zur Geschichte der doppelten Buchführung, besonders in Nürnberg. Leipzig 1907; SHELDAHL, Terry K.: Eigteenth-Century Book-keeping. New York - London 1996; BRIEF, Richard P. (Ed.): Four classics on the theory of double-entry bookkeeping. New York 1982; NOBES, Christopher (Ed.): The Development of Double Entry. Selected Essays. New York - London 1984.

24 SLAVÍČKOVÁ, Pavla: The Double-Entry Accounting System Before 1800 as an Example of a Cultural Transfer Failure. In: ČAPSKÁ, Veronika (Ed.): Processes of Cultural Exchange in Central Europe 1200-1800. Opava 2014, s. 129-147.

25 PACIOLI, Luca: Summa de Arithmetica, Geometria, Proportioni et Proportionalita. Venice 1494. Nejnovější překlad spisu do češtiny JANHUBA, Miloslav (ed.): Magister Luca Pacioli (Patiolus): Tractatus XI. particularis, de computis et scripturis, část knihy Summa de Arithmetica, geometria, proportioni et proportionalita, vydané v listopadu 1494 Benátkách. In: JANHUBA, Miloslav: Základy teorie účetnictví. Praha 2005, s. 170-216.

26 K tomuto detailně SLAVÍČKOVÁ, P.: Účetnictví.

27 SLAVÍČKOVÁ, Pavla - PUCHINGER, Zdeněk: Účetní pravidla v tisku ze 16. století z Vlastivědného muzea v Olomouci. Zprávy Vlastivědného muzea v Olomouci 310, 2015, s. 27-36.

28 Hospodár̆ : Knížka velmi užitečná, zavírajíc v sobě předně na vedení života křestanského jakby ti, kteřýž v světě nad jinými panují, sami sebe i sobě poddané spravovati mèli. Potom gruntovní správu a pořádek všelijakého hospodářství, zvláště pri panstvích a zbožích potřebná pánům, kteříž veliké statky na zemi mají. Praha: Daniel Adam z Veleslavína, 1587. Vlastivědné muzeum v Olomouci, inv. č. 16560.

29 FISCHER, Kryštof. Knihy hospodářské : oko Páně aneb dobře spořádané hospodářství polní... Praha: Jezuitská tiskárna, 1705-1706. Vědecká knihovna v Olomouci, sign. 995.775/ 1-2.

30 PLACHT, Otto - HAVELKA, František: Příručka školské a osvětové správy pro potrebu služby školských a osvětových úradů a orgánů. Praha 1934, s. 923. 
studijního plánu pro chlapce ve věku od dvanácti do osmnácti let byla i praxe, kterou vykonávali přímo na vrchnostenském velkostatku. ${ }^{31} \mathrm{~V}$ jistém smyslu výjimečnou se stala hospodářská škola na panství v Souticích u Vlašimi, kterou založil člen jinak ne přiliš významného rodu Puteani, Josef František (1749-1836). Ten také (a po jeho vzoru i jeho synové) napsal pro potřeby této školy vlastní učenice. ${ }^{32}$ Unikátní jsou tato díla v tom, že popisují zvláštní účetní techniku, kterou oni sami vyvinuli pro potřebu správy svého panství tzv. puteánské kamerální účetnictví. ${ }^{33}$

\section{Podoba účetnictví po roce 1848}

K významnému posunu ve vývoji účetnictví došlo v druhé polovině 19. století, což zřejmě souviselo s celkovou transformací společnosti po roce 1848 . Vlajkovou lodí změn se stalo vydání Všeobecného obchodního zákoníku v roce $1863 .{ }^{34}$ Tento klíčový právní předpis poprvé v naší historii vůbec vymezoval základní smysl, resp. cíl účetnictví (v soudobé terminologii ještě jako vedení obchodních knih) a určil ekonomické subjekty, které měly povinnost se ustanovením tohoto zákona řídit. ${ }^{35}$ Poprvé se v něm objevilo označení (pod soudobým pojmem) účetní jednotka, které byla zákonem uložena povinnost vést účetnictví a sestavovat jedenkrát ročně bilanci (dnes řečeno rozvahu) majetku a dluhů. ${ }^{36}$ To, co zákoník nijak neošetřoval, byla účetní soustava. Všechny ekonomické jednotky, tedy i ty, kterým byla nově uložena povinnost vést účetnictví, si mohly samy zvolit, jakou účetní soustavu budou používat.

V praxi nejrozšířenější se během 19. století stalo jednoduché účetnictví označované tehdy častěji jako kupecké, které postupně nahradilo účetnictví kamerální a tzv. správní účetnictví. ${ }^{37}$ Podvojné účetnictví (tzv. dopika), přestože bylo součástí vzdělávacích plánů na odborných školách, se v praxi oblibě přiliš netěšilo, zřejmě kvůli své složitosti. To se pokusil změnit Karel Petr Kheil st. (1817-1871), jedna z vůdčích osobností v oblasti účetnictví v tomto období, ${ }^{38}$ který navrhl v roce 1858 tzv. Kheilův podvojný účetní styl. ${ }^{39}$

31 ČERNOHORSKÝ, Zdeněk: Dějiny zemědělského školstvív Československu. Praha 1980, s. 14-15.

32 Př́mo k účetnictví zejm. PUTEANI, Karl Ferdinand: Einleitung und kurze Belehrung zur Führung der Wirtschafts - Rechnungs - Haupbücher. Prag 1807; PUTEANI, Joseph von: Grundsätze des allgemeinen Rechnungswesens. Wien 1818.

33 MIKUŠEK, Eduard: Účetní systémy a metody na majetku roudnických Lobkoviců. Sborník archivních prací 36,1968 , č. 1, s. 53-102.

34 Všeobecný obchodní zákoník č. 1/1863 ř. z.

35 Tamtéž, § 19.

36 Rozdíl IV.O knihách obchodních. Článek 28. Každý kupec povinenjest, vésti knihy, z nichž obchodjeho a stavjeho majetnosti dokonale poznati lze. Povinen jest, obdrženélisty obchodní schovávati, prepis (kopii nebo otisk) odeslaných listů obchodních za sebou podržeti a pořádem časovým do knihy přepisů vpisovati. Článek 29. Každý kupec, počínaje živnost svou, má pozemky svá, svá pohledávání a dluhy, sumu peněz, které má na hotově, a jiné částky jmění svého zevrubně sepsati, pritom hodnotu každého kusu jmění svého udati a učiniti závěru, vníž by poměr majetnosti a dluhův byl predstaven; má i na príště každého roku takový inventár a takovou bilanci jmění svého zhotovovati. Má-li kupec sklad zboží, jenž podlé povahy živnosti nehrubě každého roku může býti inventován, tehdy dosti jest, aby inventár skaldu zboží vždy po dvou létech byl predsevzat. Společnostem obchodním platí táž ustanovení, co se dotýče majetnosti společenské. Všeobecný obchodní zákoník č. 1/1863 ř. z., § 28-28. Více také § 30-31, 35.

37 SLAVÍČKOVÁ, P.: Účetnictví.

38 KUBEŠA, Jaroslav: Karel Petr Kheil otec. Účetnictví 2, 1967, č. 10, s. 372-373; TÝŽ: Účetní historik Karel Petr Kheil. Účetnictví 3, 1968, č. 3, s. 110-113.

39 Jednalo se o spis Die Lehre der Buchführung nach italienischem und Kheilscheme Systeme in doppelten Partien und den Bestimmungen des Handelsgesetzbuches. Prag 1860. 
Jeho základním principem byla redukce soustavy pouze na dvě knihy, a to deník a hlavní knihu (oproti původní struktuře tří knih). Rozšíriit se měla tato účetní soustava hlavně v průmyslových podnicích, od roku 1870 měl být jako tzv. Brožův systém (po Ferdinandu Brožovi, který jej drobně upravil) zaveden i na některých velkostatcích. ${ }^{40}$ Jestli tato soustava urychlila nástup podvojného účetnictví do praxe je předmětem dalšího výzkumu, převahu nad jednoduchým účetnictvím se mu však v tomto období získat zcela jistě nepodařilo. Souhrnně se dá říci, že typický je nadále i pro období po roce 1862 většinově soukromý charakter účetnictví, které primárně sloužilo zejména pro organizaci toků a věcí uvnitř ekonomické jednotky, jako její vnitřní kontrolní mechanismus, tedy nástroj sloužící jejím vlastním potřebám.

Odrazem této role účetnictví je i jedno z jeho odvětví, které se zejména v 19. a na počátku 20. století těšilo velké oblibě, a to bylo účetnictví pro ženy v domácnosti. Jednalo se o systém vytvořený za účelem efektivního spravování domácnosti, který si ženy mohly osvojit během školní výuky nebo později na tzv. hospodyňských školách, prrípadně samostatně $\mathrm{z}$ některé $\mathrm{z}$ mnoha prŕíruček, které pro ně různí autoři sepsali. ${ }^{41}$ Jednalo se třeba o příručku Hospodyně našeho věku (1865) Františky Hansgirgové, Domácí hospodářství (1923) Marie Trachtové, nebo spis Domácí hospodyně. Důležité pokyny hospodyňkám (1895) Karla Šafránka. V naposledy zmiňované autor v kapitole nazvané Jak má hospodyně účty vésti doporučuje obsah účetnictví přizpůsobit velkosti a charakteru domácnosti. Parafrázujeme-li v př́ručce uvedený apel, stejně jako si účetní záznamy o svém podnikání vede kupec, řemeslník, nebo průmyslník, má si tak počínat i jeho žena, která řídí domácnost, nebot' pečlivě vedené účetnictví je ideální prevencí nejen proti finančnímu nedostatku, ale zabraňuje i zbytečným svárům mezi manželi. ${ }^{42}$

\section{Účetnictví mezi léty 1918 a 1945}

Podoba účetnictví tak, jak se vykrystalizovala v době Rakouska-Uherska, zůstala zachována také v nově vzniklém Československu. V období bezprostředně po roce 1918 nelze nalézt žádný samostatný právní předpis, který by ošetřoval přímo účetnictví a jeho podobu a lze se proto domnívat, že znění Všeobecného obchodního zákoníku z roku 1863 a na něho navazujících předpisů bylo v tomto období považována za dostatečnou. ${ }^{43}$

Během existence první československé republiky tak vznikaly pouze zákony, které dílčím způsobem ošetřovaly takové účetní mechanismy, které to aktuálně vyžadovaly. Jednalo se například o zákon č. 309/1920 Sb. o dávce z majetku a dávce z přírůstku z majetku, ${ }^{44}$ který upravoval i pravidla pro oceňování majetku v rámci účetnictví a sestavování bilancí. ${ }^{45}$ Podobný charakter měly i další předpisy, jako prríklad uved'me zákon

\footnotetext{
$40 \quad$ KUBEŠA, Jaroslav: Kjubileu vydání dvou Kheilových prací. Účetnictví 1, 1968, č. 10, s. 364-366.

41 SLAVÍČKOVÁ, Pavla - DVOŘÁKOVÁ KANĚČKOVÁ, Eva - PUCHINGER, Zdeněk: Účetnictví jako součást výchovy žen-podnikatelek. In: SLAVÍČKOVÁ, Pavla (ed.): Ženy - podnikatelky v minulosti a současnosti. Praha 2016, s. 52-70.

42 ŠAFRÁNEK, Karel: Domácí hospodyně: Dưležité pokyny hospodyňkám. Chrudim 1895, s. 16.

43 Detailněji k tomuto PUCHINGER, Z. - SLAVÍČKOVÁ, P.: Malé dějiny.

44 Zákon č. 309/1920 Sb., o dávce z majetku a dávce z př́růstku na majetku.

45 Pro ocenění součástek jmění jest rozhodnou obecná (prodejní) cena, pokud zákon jinak nestanoví. Součástkami jmění jsou hospodářské jednotky, t.j. věci nebo práva, která z hospodářských ohledů bud'sama pro sebe trvají nebo s jinými věcmi nebo právy $k$ sobě náležejí. Hospodářsky samostatné věci nebo práva oceňují se jednotlivě, věci a práva, které jsou dohromady hospodářskou jednotkou, oceňují se jako celek. Tamtéž, § 10.
} 
č. 404/1922 Sb., který nařizoval, aby hospodaření státních podniků bylo pokud možno přizpůsobeno hospodaření podniků soukromých. ${ }^{46}$

Také ve výuce účetnictví nedošlo k zásadním změnám bez ohledu na reformu obchodního školství, která proběhla v roce $1922 .{ }^{47}$ Vedle obchodních škol bylo účetnictví v široké míře vyučováno také na školách průmyslových a živnostenských, při menší hodinové dotaci i na celém spektru dalších škol od různých večerních kurzů až po školy vysoké. V učebních osnovách nadále dominovaly učebnice autorů, kteří působili již v dobách Rakousko-Uherska, jako byl literát a pedagog, zakladatel vlastní obchodní školy Antonín Skřivan, ${ }^{48}$ zmíněný Karel Petr Kheil ${ }^{49}$ nebo učitel a přední odborník na teorii účetnictví Josef Pazourek. ${ }^{50}$ Podle Př́ručky školské a osvětové správy $(1934)^{51}$ se původně vyučovala nadále zejména jednoduchá soustava, postupně se však obsah výuky proměnil, a to ve prospěch podvojného účetnictví a, jak máme dochováno v dobové vzpomínce Josefa Ťalského, byl dáván při cvičení větší prostor obtížnějším případům. ${ }^{52}$

\section{Charakter účetnictví v období 1946 až 1989}

Kzásadnímu zlomu došlo po skončení války, a to zejména v souvislosti se znárodňováním podniků. Pro ty bylo nutno nově definovat zásady a pravidla pro vedení účetnictví. Základním dokumentem se stal zákon č. 116 z roku 1946 Sb. o jednotné organisaci podnikového početnictví. ${ }^{53}$ Ten zavedl na místo účetnictví do praxe pojem podnikové početnictví, pod nímž vzhledem $\mathrm{k}$ potřebám centrálně řízené podnikové sféry bylo zahrnuto účetnictví spolu s kalkulacemi, statistikou a rozpočetnictvím. ${ }^{54}$ Mezi další klíčové právní předpisy

\footnotetext{
46 Aby hospodaření státních závodů, ústavů a pod. (státních podniků) bylo pokud možno prizpůsobeno hospodaření podniků soukromých a aby za tím účelem i správa podniků těch byla podle potřeby a povahy toho kterého podniku více osamostatněna, usnesla se vláda ve schůzi konané dne 7. července 1922 na tom, aby rozpočty těchto státních podniků byly do jisté míry odloučeny od rozpočtu běžného státního hospodářství [...] Dále bylo vládou dne 7. července 1922 usneseno, aby účtováni státních závodů, ústavi̊ a pod. ve lhủtě co nejkratší bylo pretvoreno na účtování komerční. Zákon č. 404/1922 Sb., o úpravě hospodaření ve státních závodech.

47 Zákon č. 73/1922 Sb., jímž se upravuje vyučování v naukách obchodních, moderních jazycích, v krasopise, v těsnopise a ve psaní na stroji.

48 SKŘIVAN, Antonín: Bibliotheka kupecká. Soubor vědomostí každému kupci potřebných. Praha 1862; TÝŽ: Nauka o kupeckém účetnictví. Praha 1874.

49 KHEIL, Karel Petr: Účetní príklady k praktickému prováděnív knihách obchodních. Praha 1891; TÝŽ: Materialie ku podvojnému účetnictví. Praha 1888.

50 PAZOUREK, Josef: Účetnictví podvojné a různé jeho způsoby. Hradec Králové 1900; TÝŽ: Učebnice účetnictví podvojného pro obchodní akademie. Praha 1906-1907.

51 PLACHT, Otto - HAVELKA, František: Př́ručka školské a osvětové správy pro potřebu služby školských a osvětových úřadio a orgánů. Praha 1934.

52 Probrala se část účetnictví prostého, a sice v 1. běhu theorie účetnictví, výklad kněh odbočných i principálných, př čemž pracovali posluchači některé krátké rozečty; ve 2. běhu počaly práce praktické zkoušením účtů v hlavní knize, byl-li úvěr daný, neb nám vyměrený vyčerpán, na to provedeny všecky způsoby výpisů běžících účtů, a sice tak, že se pracoval vždy jeden př́klad ve škole, druhý pak dán za práci domácí. Po ukončení těchto cvičení pracovali posluchači tř́ měsíční dobu z obchodu ve velkém, provedše celou závěru dle zásad účetnictví jednoduchého neb prostého. Při všech pracích bral se zretel k názvosloví i frazeologii německé. Převzato z: KUBEŠA, Jaroslav: Památce prvního profesora účetnictví na Českoslovanské akademii obchodní v Praze. Účetnictví 7, 1972, č. 10, s. 312.

53 Zákon č. 116/1946 Sb., ojednotné organisaci podnikového početnictví a na něho navazující zákon č. 204/1946 Sb., kterým se mění některé předpisy o obchodních knihách.

54 Prozatímní Národní shromáždění republiky Československé usneslo se na tomto zákoně: $\$ 1$ (1) Podnikové početnictví se jednotně organisuje podle zásad, které stanoví vláda nařízením. Při tom budiž dbáno, aby podnikové početnictví vyhovovalo potřebám hospodárského plánování, zvláštním potřebám jednotlivých hospodárských odvětví, jakož
} 
z tohoto období pak náleží zejména vládní nařízení č. 205 z 5. listopadu 1946, kterým se stanovovaly jednotné účetní zásady. ${ }^{55}$ Poprvé v naší historii toto vládní nařízení řešilo i účetní soustavu a nařizovalo, že nově měly podniky a firmy evidovat svoji hospodářskou činnost jednotně, a to za pomoci podvojného účetnictví. Jistým způsobem signifikantní je to, že tento přelomový zákon měl pouze několik málo odstavců. ${ }^{56}$

Na rozdíl od období před druhou světovou válkou je podoba účetnictví mezi léty 1946 a 1989 charakteristická svojí jednotností, přičemž dominantním (a vlastně jediným) hráčem na tomto poli se stává stát a jeho zájmy. Podobu účetnictví v tomto období určovala nově vydávaná legislativa, které se museli podřídit nejen samotní uživatelé, ale i systém školní výuky. I tak je ale na první pohled jednotné období možné rozdělit do několika fází, které vymezuje vydání významných právních předpisů.

V první fázi účetnictví reagovalo na sadu postupně vydávaných zákonů o znárodnění jednotlivých firem až na úroveň drobných provozoven a řemeslných podniků - v návaznosti na tyto zásahy do ekonomiky bylo v rychlém sledu vydáváno velké množství nových předpisů. Jednalo se zejména o různé vyhlášky, které stanovovaly okruh podniků, pro které postupně vznikala povinnost řídit se jednotnými účetními zásadami. Zároveň tato legislativa prohlubovala a zpřesňovala jednotlivé účetní principy a kategorie. Mezi 1946 a 1951 tak byl položen základ pro sledování hospodářské činnosti velké většiny ekonomických subjektů působících na území tehdejšího Československa. ${ }^{57}$

Novou etapu vývoje započal zákon č. 108/1951 Sb., o organisaci národohospodářské evidence a k němu vydané vládní nařízení č. 41 ze srpna 1952. ${ }^{58}$ Tyto právní předpisy vymezovaly soustavu národohospodářské evidence (nově zavedený terminus technicus), která se skládala z evidence operativně technické, evidence účetní a statistiky. Spolu s tím byla uložena všem ekonomickým subjektům zákonná povinnost podávat správně, pravdivě a včas všechny údaje a zprávy, které budou orgány evidence a statistiky vyžadovat, což se týkalo jak závodů, podniků, úřadů, organizací a dalších institucí, tak i majitelů soukromých hospodářství, jakož i všem obyvatel.

\footnotetext{
i potřebám daňovým. (2) Podnikovým početnictvím podle tohoto zákona se rozumějí účetnictví, kalkulace, statistika a rozpočetnictví podniků všeho druhu. Zákon č. 116/1946 Sb.

55 Vládní nařízení ze dne 5. listopadu 1946 č. 205 Sb., o jednotné organisaci podnikového početnictví.

56 Za zlomové jsou obvykle považovány první dva: § 1 Účetnictví organisované podle tohoto nařízení musí: a) zachycovati písemně a usporádaně stav a změny majetku (aktiv) a kapitálu (cizího neboli pasiv a vlastního neboli čistého jmění), náklady a výnosy a zjištovati hospodářský výsledek podniku (zisk nebo ztrátu); b) poskytovati údaje potřebné pro hospodářské plánování a pro účely daňové a umožňovati zjištování hospodárnosti podniků a jejich kontrolu; c) býti v takovém vzájemném vztahu s ostatními obory podnikového početnictví, aby bylo možno kontrolovati a ověrovati jejich výsledky. § 2 V podnicích se musí vésti podvojné účetnictví. Vládní nařízení č. 205/1946 Sb.

57 Detailněji viz: PUCHINGER, Zdeněk - SLAVÍČKOVÁ, Pavla: Vývoj legislativní úpravy účetnictví mezi léty 1918 a 1951. In: PUCHINGER, Z. - SLAVÍČKKOVÁ, P.: Malé dějiny, s. 78-107.

58 Zákon č. 108/1951 Sb., o organisaci národohospodářské evidence; Nařízení č. 41/1952 Sb., kterým se stanoví zásady pro účetní evidenci (účetní zásady). Další právní předpisy se vztahem k této věci: Vyhláška č. 1/1951 Ú. 1 ., kterým se stanoví zásady pro jednotné oceňování v podnikovém početnictví; Vyhláška č. 37/1951 Ú. 1., kterou se stanoví okruh podniků povinných řídit se zásadami pro jednotné oceňování v podnikovém početnictví, jakož i rozsah a doba vzniku této povinnosti; Vyhláška č. 116/1951 Ú. l., kterou se vydávají první závazné směrnice k zásadám pro jednotné oceňování v podnikovém početnictví; Vyhláška č. 190/1951 Ú. l., kterou se vydávají závazné směrnice pro depositní účetnictví a pro evidenci některých druhů finančního majetku v peněžních ústavech; Vyhláška č. 244/1951 Ú. 1., kterou se mění a doplňují závazné směrnice pro kalkulaci v obchodních podnicích; Vyhláška č. 361/1951 Ú. 1., o úpravě rozpočetnictví; Vyhláška č. 55/1952 Ú. l., o povinnostech, právech a odpovědnosti hlavních (vedoucích) účetních a o organisaci účetní služby; Vyhláška č. 72/1952 Ú. l., o účinnosti účetních zásad pro některé okruhy účetních jednotek aj.
} 
Tento právní rámec byl pak novelizován ve dvou vlnách. Nejprve v 60. letech v návaznosti na Šikovu ekonomickou reformu se jednalo o zákon č. 23/1963 Sb., o lidové kontrole a o národohospodářské evidenci ${ }^{59}$ a poté na počátku 70. let zákonem č. 21/1971 Sb., a na něho navazujícími předpisy. ${ }^{60} \mathrm{~V}$ této etapě vývoje se součástí účetnictví staly i kalkulace používané jako základ pro tvorbu cen, čímž dostalo účetnictví i významný ekonomicko-společenský rozměr. ${ }^{61}$ Vydání zmiňovaného zákona č. 21/1971 znamenalo dovršení transformace účetnictví do podoby pouhé součásti nově vytvořené jednotné informační soustavy organizací.

Samotný pojem účetnictví se v určitém smyslu vytratil, a to jak z legislativy, tak i ze školných osnov. V letech 1947 až 1952 se označovalo jako podnikové početnictví, ${ }^{62}$ od roku 1953 do 1965 už jen jako národohospodářská evidence, ${ }^{63} \mathrm{v}$ druhé polovině 60 . let se sice krátce vrací termín účetnictví, ${ }^{64}$ aby se po roce 1971 připojilo do zmíněné jednotné informační soustavy organizací ${ }^{65}$ (předmět byl označován jako informační soustava podniku). Podobně se proměňoval také cíl výuky a její náplň. ${ }^{66}$ Podle učební osnovy z roku 1955 bylo účetnictví a statistika zařazeny ještě mezi tzv. osové předměty, tedy ty, které tvořily hlavní odbornou náplň učebních osnov, a to spolu se socialistickým hospodářstvím, hospodářskými počty, základy čs. práva a technikou hospodářské administrativy. ${ }^{67}$ Učebním cílem bylo vychovat kvalifikované účetní pracovníky pro jednotlivá odvětví státem řízené ekonomiky, kteří budou schopni sledovat a kontrolovat plnění státního plánu rozvoje národního hospodářství a státního rozpočtu a poskytovat podklady pro jejich sestavování. ${ }^{68}$ Už ale učební osnova z roku 1957 posunula požadavek na absolventy dále v tom směru, že již

\footnotetext{
59 Zákon č. 23/1963 Sb., o lidové kontrole a o národohospodářské evidenci.

60 Zákon č. 21/1971 Sb., o jednotné soustavě sociálně ekonomických informací. Návazné předpisy: Nařízení č. 153/1971 Sb., o informační soustavě organizací; Vyhláška č. 154/1971 Ú. l., o účetnictví; Vyhláška č. 155/1971 Sb., o inventarizacích hospodářských prostředků; Vyhláška č. 88/1972 Ú. l., o prověřování a schvalování ročních účetních závěrek státních hospodářských organizací a o organizaci zahraničního obchodu.
}

61 Zákon č. 21/1971 Sb., § 2: Informační soustava zahrnuje: a) Informace získávané soustavným a průkazným sledováním a hodnocením stavu a pohybu hospodářských prostředků (a jejich zdrojü) a hospodářských výsledkủ (informace z oboru účetnictví), b) Informace sloužící k měrení, hodnocení a ke kontrole hospodářské činnosti uvnitř organizací (informace z oboru rozpočetnictví), c) Informace získávané vyčíslováním a hodnocením jednotlivých složek ceny výkonů a zkoumáním jejich vývoje (informace z oboru kalkulace), d) Informace o stavu a vývoji hromadných sociálně ekonomických jevü, získávané statistickými metodami vorganizacích (informace z oboru statistiky), e) Operativní záznamyo sociálně ekonomických skutečnostech (informace z oboruoperativní evidence),f) Informace obsaženéve zvlášt organizovaných evidencích, pasportech a rejstř́cích, poprípadè jiné informace sociálnè ekonomického charakteru.

62 Viz např. FUKS, Svatomír: Podnikové početnictví pro každého:Základy účetní techniky a organisaze s př́klady. Praha 1948; FIALA, Josef: Podnikové početnictví. Praha 1948; KOCMAN, Michael: Podnikové početnictví v hospodářské samosprávě : Praxe postup. Methody provozního účetnictví. Praha 1949; Předpisy pro podnikové početnictví v průmyslu. Praha 1950 aj.

63 Viz např. RUPRICH, Jiří - TESAŘ, Stanislav: Národohospodářská evidence : (Mechanizace administrativy v les. hosp.). Praha 1963; KOŘíNEK, František: Národohospodářská evidence. Praha 1962; VYSUŠIL, Jiří: Národohospodárské plánování a evidence. Praha 1966.

64 Viz např. SLONEK, Vladimír: Účetnictví a kalkulace. Brno 1970.

65 Viz např. ŽÁK, František: Informační soustava podniku. Praha 1981; VOREL, Otakar: Informační soustava podniku. Praha 1979; KOUDELA, Jiří: Informační soustava podniku. Praha 1989; KLAINOVÁ, Naděžda: Informační soustava podniku. Valašské Meziříčí 1991.

66 MAUER, Josef: Literatura pro vyučování účetnictví na středních ekonomických školách od roku 1946. Účetnictví 20, 1985, č. 10, s. 378-380.

67 Tamtéž.

68 MAUER, Josef: Vyučování účetnictví na středních ekonomických školách po druhé světové válce. Účetnictví 18,1983 , č. 4, s. $158-160$. 
neměli být pouhými registrátory hospodářských skutečností, ale měli se stát hospodáři, kteř́ dovedou stav a výsledky hospodarení správně analyzovat a hodnotit pro potřeby vlastní, pro potřeby nadřizených účetních jednotek a pro účely dalších organizací a institucí. ${ }^{69}$ A konečně v roce 1966 bylo stanoveno, že absolvent má vědět, že účetnictví jako součást soustavy sociálně ekonomických informací je nástrojem ř́zení, sestavování a kontroly plnění plánu a rozpočtu, včetně plánů a rozpočtů vnitropodnikových. ${ }^{70}$

Ještě před změnou politického systému v roce 1989 stihlo získat účetnictví novou podobu, která symbolicky završila vývoj předchozích padesáti let, a to zákonem č. 128/1989 Sb., kterým se doplňoval zákon z roku $1971 .{ }^{71}$ Klíčovým rysem tohoto zákona bylo využití účetnictví jako nástroje kontroly hospodařících jednotek vzhledem k centrálně řízenému systému plánované ekonomiky. Přesto tento právní předpis zůstal v platnosti ještě několik let po pádu totality a zavedení tržní ekonomiky, a to až do vydání zákona č. 563/1991 Sb. o účetnictví, který v aktuálním znění platí dodnes.

\section{Závěr}

Důležitým poznáním je fakt, že od středověku až do druhé poloviny 19. století stát účetnictví fakticky nijak nereguloval, a i po zavedení Všeobecného obchodního zákoníku v roce 1863, což lze označit jako klíčový mezník, přistupoval i nadále k účetnictví velmi liberálně. Změnu v tomto nepřinesl ani pád monarchie a vznik Československé republiky. Po celé toto období bylo ponecháno v pravomoci uživatelů, aby si sami rozhodovali o metodách např. pro oceňování majetku, samy si stanovili, jaká data a v jaké struktuře jim má účetnictví poskytovat a v neposlední řadě si i zvolily soustavu pro vedení účetnictví (ve středověku a raném novověku šlo většinou o tzv. správní účetnictví, později převládlo účetnictví kamerální a jednoduché).

Výsledná podoba účetnictví v praxi pak byla přímo závislá na znalostech konkrétního člověka, který účetnictví vedl, a na tradici či zvyklostech, které byly v podniku zavedeny. Ty obvykle přetrvávaly beze změny i řadu desetiletí. Tato dlouhodobá setrvačnost (můžeme říci konzervativismus), který lze na soudobých účetních záznamech vysledovat, je v prímém kontrastu s obrovskou mírou svobody, kterou ekonomickým subjektům v účetnictví v tomto období ponechával stát.

Vznik systematizované výuky účetnictví v druhé polovině 19. století sice přinesl do oboru více profesionality, nicméně k úplné unifikaci účetnictví ani poté nedošlo. Spíše lze mluvit o různých proudech nebo směrech v přístupu k vedení účetnictví, reprezentovaných klíčovými osobnostmi, jejichž výukou prošlo několik generací studentů, kteří pak své znalosti šírili dále do praxe.

Bez zajímavosti není v tomto období ani role podvojného účetnictví. Není pochyb o tom, že pouze tato účetní soustava díky své struktuře umožňovala a stále umožňuje uživateli zjistit, zdali se jeho hospodaření nachází v zisku nebo ztrátě, jaké zdroje a v jaké výši měl nebo bude mít k dispozici, díky čemuž by měl být schopen racionálně posoudit důsledky svých minulých ekonomických rozhodnutí a naplánovat různé možnosti investování v budoucnu. Zatímco v zemích zejména západní Evropy bylo podvojné účetnictví

\footnotetext{
69 Tamtéž.

70 Tamtéž.

71 Zákon č. 128/1989 Sb., kterým se doplňuje zákon č. 21/1971 Sb., o jednotné soustavě sociálně ekonomických informací. K tomu navazující: Nařízení č. 136/1989 Sb., o informační soustavě organizací.
} 
v praxi využíváno již od doby vrcholného středověku, ${ }^{72}$ na účetní praxi v našem prostředí však můžeme vidět, že většina ekonomických subjektů s přechodem na podvojné účetnictví nijak nespěchala. ${ }^{73}$ Důvodem mohla být skutečnost, že nekompetentnost uživatele mohla vést i v tak technicky vyspělé soustavě, jako bylo podvojné účetnictví, k vytváření nekonzistentních, mnohdy až chaotických účetních výkazů a působit tak uživateli více škody než užitku.

Jinak řečeno, pohlížet na účetnictví v minulosti skrze současnou optiku může být kardinálním neporozuměním jeho funkci a účelu. Cílem vedení účtů v tomto období nebylo primárně sledovat výkonost hospodaření, ale zajistit solventnost ve smyslu vyrovnané bilance mezi př́jmy a výdaji, resp. to, zdali je podnik schopen dostát svým závazkům. Zejména v nejstarším období mělo přitom účetnictví i další funkce, jejichž význam mohl být vyšší než ekonomická funkce - účty byly vedeny jako nástroj pro uchování paměti o významných skutečnostech, jako důkazní prostředek pro př́ípadné soudní spory, při úvěrovém hospodaření měly sloužit jako ochrana věřitele před dlužníkem a apod.

Souhrnně řečeno, charakter účetnictví v našem prostředí byl až do novověku ryze soukromý. To v praxi znamenalo, že uvedená data, která účetnictví dokázalo generovat, sloužila výhradně vnitřní potřebě správce nebo vlastníka majetku, oproti současnosti, kdy účetnictví preferuje data užívaná k účelům vnějším (daňovým, evidenčním, statistickým aj.). Dokladem pro toto tvrzení je bezesporu zmíněná absence legislativních předpisů, které by strukturu a obsah účetnictví jakkoliv upravovaly. Svůj vliv na to měla i dobová podoba daňového systému. Kde není poptávka, není ani nabídka, jinak řečeno potřeba, aby účetní soustava zachycovala takové operace, na jejichž základě by bylo možné vyměřit příslušnou daň, v minulosti jednoduše neexistovala, což zpětně nepodněcovalo zájem státu a jeho orgánů, aby do podoby účetnictví (a použité účetní soustavy) jakkoliv vstupovaly a regulovaly, případně sjednocovaly jeho obsah a strukturu. Účetnictví tedy v této fázi fungovalo jako nástroj v rukách vlastníka, který si jeho pomocí udržoval kontrolu nad svým majetkem. Středověký stát, rakouská, později rakousko-uherská monarchie ani první a druhá Československá republika celý potenciál účetnictví ve svůj prospěch nikdy nevyužily.

Změna přišla až s koncem druhé světové války, kdy do této doby z upozaděného oboru ponechaného soukromým účelům se účetnictví změnilo v klíčový zdroj informací v rámci připravované a následně i realizované představy o centrálním, plánovitém řízení ekonomiky. Základem se stal obrovský legislativní aparát, který nově reguloval všechny účetní pochody až do nejmenšího detailu, a na něho navázaný vzdělávací systém. Transformace účetnictví do podoby nástroje pro sběr dat pro potřeby centrálních orgánů však fakticky znamenala zánik účetnictví jako samostatné disciplíny a jeho splynutí s dalšími odvětvími. Nejpozději od 70. let tak účetnictví bylo pouze jedním z mnoha oborů v rámci nově

\footnotetext{
72 Je doložené, že i Luca Pacioli se při psaní svého díla opíral o reálné znalosti z praxe. Taylor, R. Emmett: Luca Pacioli. In: Littleton, Ananias Charles - Yamey, Basil S. (Eds.) Studies in the History of Accounting. Illinois 1956, s. 175-184. K nejstaršímu období účetnictví v Itálii viz např. Lee, Alan Geoffrey: The Development of Italian Bookkeeping 1211-1300. Journal of Accounting and Business Studies 9/2, 1973, pp. 137-155. O míře rozšíření podvojného účetnictví v praxi nejen v Itálii, ale i Francii nebo Anglii vznesl pochybnosti Basil S. Yamey. Srov. YAMYE, Basil S.: Scientific Bookkeeping and the Rise of Capitalism. The Economic History Review. New Series 1, 2/3, 1949, s. 99-113.

73 Detailní výzkum na rozšíření této účetní soustavy v praxi dosud nebyl proveden. Konstatovaná skutečnost je odvozena zejména od struktury učebních osnov na straně jedné a zmínek, které se objevují v textech autorů 19. a první poloviny 20. století. Viz: Výuka a učebnice účetnictví a Účetnictví jako věda: Významné osobnosti a díla in: PUCHINER, Z. - SLAVÍČKOVÁ, P.: Malé dějiny.
} 
vybudované jednotné informační soustavy. Tehdy se účetnictví stává aktivním nástrojem státu, i když hlavně skrze informace, které mu poskytuje pro potřeby řízení.

Je zajímavou skutečností, že účetnictví po roce 1989 si více než z prvorepublikové tradice vzalo inspiraci z období totality. Zákon z roku 1989 byl sice nahrazen v roce 1991 novým legislativním předpisem, který vyhovoval podmínkám nově nastolené tržní ekonomiky, informační funkce účetnictví tak dobře fungující za předchozí doby se však stát nevzdal. Jednoznačné upřednostnění potřeb státu před soukromými potřebami samotných uživatelů lze doložit i nařízením o povinném použití podvojného účetnictví, které se (po většinu času) vztahovalo i na zcela malé subjekty. Obrovské možnosti, které účetnictví jako nástroj pro řízení toků ve státě poskytuje, tak naše současnost využívá beze zbytku. Účetnictví samotné a jeho základní principy přitom zůstávají stejné, jako byly v minulosti, liší se pouze účel, za kterým jsou účetní záznamy vedeny.

\section{Summary}

\section{Changes of Purpose of Accounting in Different Periods of the Czech State}

The aim of the article is to describe the purpose of accounting in various period of the history of the Czech state in relation to the state legal system, and to answer the question whether there is a connection between the state and its establishment and the content and form of the accounting system used at that time.

The article is divided into five parts. The first part summarizes the Czech historiography on the history of accounting, the second describes the basic features of accounting before 1848 and the third follows the development of accounting after this year especially in connection with the issue of the General Commercial Code of 1862. The fourth part of this article discuses accounting and its character in the period of 1918 and 1948 and the last one focuses on changes after 1946, resp. 1948. In all these time periods, accounting was able to follow the changing needs of users, whether internal (accountant, manager, owner, etc.) or external (local authority, government etc.); however, its purpose changed.

The most important findings are that that since the Middle Ages until the second half of the $19^{\text {th }}$ century, accounting was unregulated by the state. Even after the issue of the General Commercial Code in 1862, the approach of the state to accounting was very liberal. It did not change even after the establishment of the first Czechoslovak Republic. Throughout this period, the users could freely choose an accounting system, decide on the methods of recording e.g. the valuation of assets, and determine what data and in what structure accounting records should provide, etc. The nature of the accounting was private in the period before 1946, resp. 1948. It means that accounting primarily served as a tool for users; it helped them to organize flows and items within the economic unit. The content and structure of accounting was strongly dependent on the user's own knowledge of accounting theory and practice. Later, it was influenced by the leading personalities in the field of accounting science and education, such as Kheil, Brož, Pazourek, etc.

The main breakthrough occurred after the end of the World War II, particularly in connection with the transition to the central planned economy. A mighty legislative framework served as a background, which regulated accounting to the smallest detail; and a system of education connected with it. These changes led to the fundamental transformation of the purpose of accounting. In the period between 1948 and 1989, accounting became an instrument for collecting data for the needs of the state and also one of the tools for the management of the state. The transformation of accounting into this form actually meant the end of accounting as a separate discipline. It merged accounting with other branches controlled by the state (calculations, statistics, price planning, etc.). No later than since the 1970s, accounting was only one of many disciplines within the newly established unified state information system. This use of accounting then became a model for its form and use after 1989. 